\title{
Applicability of Climate Analogues for Climate Change Adaptation Planning in Bugabira Commune of Burundi
}

\author{
Risper Nyairo ${ }^{1}$, Richard Onwonga ${ }^{1}$, Kipruto Cherogony ${ }^{2} \&$ Eike Luedeling ${ }^{2}$ \\ ${ }^{1}$ Department of Land Resource Management and Agricultural Technology, University of Nairobi, Nairobi, \\ Kenya \\ ${ }^{2}$ World Agroforestry Centre (ICRAF), Nairobi, Kenya \\ Correspondence: Risper Nyairo, Department of Land Resource Management and Agricultural Technology, \\ University of Nairobi, Nairobi, Kenya. Tel: 254-723-896-243. E-mail: bunyarisper@yahoo.com
}

Received: July 9, 2014 Accepted: September 4, 2014 Online Published: October 8, 2014

doi:10.5539/sar.v3n4p46 URL: http://dx.doi.org/10.5539/sar.v3n4p46

\begin{abstract}
Climate analogue analysis is an approach that has been proposed in climate change impact studies to serve as a complement to climate impact projections. In this approach, a location whose present climate is similar to the projected climate of another location is investigated to learn about potential impacts of climate change, based on a real-life example. Possible response options to negative impacts may also be identified for climate change adaptation planning. The current study used the climatic distance method to determine analogue locations for Bugabira Commune in Burundi. The climatic distance was calculated from temperature and rainfall projections produced by three climate models, driven by two greenhouse gas emissions scenarios and assessed for three future time periods. Information relevant to farming systems and adaptation was then obtained through interviews that involved 450 household heads living in Bugabira (target) and Bubanza (analogue) communes in Burundi. By comparing the two farming systems using results from the analysis of the questionnaires, similarities and differences were determined. The analysis showed that crop and animal types, as well as various land management practices, were similar in both locations. Slight differences in land management strategies could only be noticed in the adoption rates of various technologies. Fifty-nine percent and $19 \%$ of farmers at the target and analogue locations, respectively, practiced contour ploughing, while $68 \%$ and $43 \%$ of farmers at the target and analogue locations practiced crop rotation. Eighty-seven percent of farmers at the target site and 58\% of farmers in the analogue location applied manure to their farms. The differences in adoption rates could not be attributed to climatic or non-climatic factors. Based on the results, the study concluded that the analogues approach has low potential for the farmers of Bugabira to learn lessons for adaptation planning.
\end{abstract}

Keywords: climate change, climate models, climate analogues, adaptation, farming systems

\section{Introduction}

Anthropogenic emissions of greenhouse gases are changing the Earth's climate at present (Ring et al., 2012; Braconnot et al., 2007), and this change will likely continue despite current attempts to mitigate global warming (Meehl et al., 2005; Ramirez-Villegas et al., 2013). Climate variability and change are threats to farmers because crop and animal production directly rely on both rainfall and temperature (Challinor et al., 2007; Calzadilla et al., 2013). Smallholder farmers in Sub-Saharan Africa are highly susceptible to climate change because of their strong reliance on rainfed agriculture. Their vulnerability is heightened by other factors such as declining soil fertility, poverty and inadequate access to markets, information and technology (Antwi-Agyei et al., 2013).

A number of approaches have been proposed to help farmers adapt to the changing conditions. The most common scientific approach to climate change adaptation is the use of models to project the impacts of climate change (Millar et al., 2007; Challinor et al., 2009; Randall \& Wood, 2007). Appreciation of likely impacts of climate change then facilitates the finding of suitable adaptation options. For agricultural adaptation, such projections have often relied on process-based models (e.g. crop models; Tao et al., 2009; Challinor et al., 2004) or on ecological niche modeling (Peterson, 2006; Peterson \& Shaw, 2003). While both approaches have produced useful results in many cases, they suffer from certain limitations that have often restricted their effectiveness in identifying land management strategies for adaptation. Both modeling approaches require extensive calibration, for which adequate datasets are often not available (Nelson et al., 2009; Lobell \& Burke, 
2010); process-based models are often unavailable for important crops (Müller et al., 2011); and models are normally unable to adequately capture the complex and dynamic cropping systems present on most African farms (Hijmans \& Graham, 2006; Thuiller et al., 2004; Müller et al., 2010). Of particular importance is that modeling studies simulating the impacts of climate change on agricultural productivity often exclude considerations of adaptive capacity, which are important in determining the actual impacts of future climate change (Dixon et al., 2014; Lobell \& Burke, 2008; Muñoz et al., 2013). Human systems are socio-economically dynamic, but this is seldom reflected in models.

Climate analogues have been promoted as a possible approach to overcome many of the limitations of crop and niche models and as a complement to model projections (Hallegatte et al., 2007). The approach proposes that for most target locations on earth, the projected future climate can already be observed today, albeit in another location (Arnbjerg-Nielsen, 2012). In analogue analysis, the projected future climate of a site is used to select a location where those conditions can be found today (Ramirez-Villegas et al., 2011; Luedeling \& Neufeldt, 2012). This space-for-time substitution provides an opportunity for on-the-ground empirical validation of model projections with the advantage of providing real-life scenarios that can be easily interpreted and identified with (Veloz et al., 2012). The procedure assumes that all baseline conditions in the two sites are generally similar and that the only important difference is in the climate. Because of its different climate, it is expected that the analogue location has developed different systems from those at the target site and that farmers in the target location may learn lessons for adaptation from practices that are currently being used at the analogue site (Hallegatte et al., 2007). It is expected that at the analogue location, farmers and other stakeholders may interact with presently existing agricultural systems as opposed to dealing with abstract projections of hypothetical scenarios. The approach may present an opportunity for comparative research between future and present. It could also facilitate farmer-to-farmer exchange of knowledge on adaptation options (Kellet et al., 2011). Analogues may feature different crop species or varieties than the target site and thus serve as sources of germplasm, on which breeding efforts could be based (Burke et al., 2009). The distance between the target location and its climate analogue may provide an indicator of the extent of the adaptation that may need to be carried out in the target location (Kellet et al., 2011). By evaluating agricultural systems at the analogue location, climate analogues may also be used to test the adaptive capacity of farmers. Changes in practices and production levels over time in the analogue location may be used as indicators of the mechanisms adopted to reduce vulnerability and enhance resilience of households. Climate analogues may also be used as testing grounds for recommended practices (Luedeling \& Neufeldt, 2012; Luedeling et al., 2013). Despite its promise as an adaptation tool, the analogue approach has rarely been applied in practice. It is not clear whether the approach would work in all places or contexts, and whether it can provide useful indications of promising adaptation strategies. In this study the usefulness of the analogue approach was evaluated for adaptation planning in Bugabira commune in Kirundo Province of Burundi as part of a larger project aimed at improving agricultural production and enhancing resilience in the area.

Close to $90 \%$ of the total population in this area are small-scale subsistence farmers who rely on rain-fed agriculture, and who may be strongly affected by changes in climatic conditions. Already in the recent past, this area has been hit by prolonged droughts (Minani et al., 2013). According to the International Disaster Database (CRED, 2009), drought occurrence in Bugabira and Kirundo Province at large began in 1999 and has become more frequent and severe, with the most recent drought occurring in 2010. In some seasons heavy rainfall causes flooding, which may destroy lives and property (Butterfield et al., 2011). High poverty levels and a rapid population growth of 2.9 per cent per annum (MINAGRIE, 2012), coupled with insufficient knowledge on available farming techniques limit the use of external inputs and the application of technologies. These factors limit the adaptive capacity of farmers, who are already disadvantaged by virtue of their geographical location and climate type (tropical savanna), which exposes them to weather extremes (Butterfield et al., 2011; IMF, 2012).

This paper evaluates the usefulness of the climate analogue approach for assisting adaptation of this community to climate change by: (i) finding a location whose present climate resembles the future projected climate of Bugabira Commune and (ii) comparing farming systems in the two locations, focusing on the extent to which differences between systems are related to climate.

\section{Materials and Methods}

\subsection{The Study Area}

Bugabira commune is located at approximately $2.31^{\circ} \mathrm{S}$ and $30.04^{\circ} \mathrm{E}$ with altitude ranging between $1000 \mathrm{~m}$ and $1500 \mathrm{~m}$ above sea level. Rainfall is bimodal, with $1032 \mathrm{~mm}$ of annual precipitation falling during two distinct rainy 
seasons: a short rainy season from September to December and a long rainy season from February to May. Mean annual temperature is approximately $20.5{ }^{\circ} \mathrm{C}$ (MINATTE, 2007). The area of the commune is $235 \mathrm{~km}^{2}$ and the population in 2010 was approximately 93,600 inhabitants (ISTEEBU, 2014). The commune is hilly, with slopes largely ranging from 5 to $40 \%$ and availability of flat land (0-5\% slope) being very limited. Much of this flat land consists of low-lying marshlands. Farmers draw their livelihoods from subsistence farming in a climate that has been classified as "moderate" tropical savanna. Forest cover is sparse and the area lacks permanent rivers. The most common soils are lithosols (FAO, 1988), which are ferralitic in nature, indicating partly-weathered acidic soils of generally low fertility. More fertile organosols (CSIRO-ACLEP, 2006) are found in the lower valleys (MINATTE, 2007).

\subsection{Analogue Analysis}

The analogue search procedure was based on the climatic distance method. Climatic distance is a metric to quantify the similarity between different climates. It can be used to compare the current climate of every location (cell of a spatial grid) with the projected future climate at the site of interest. The location, for which the climatic distance is minimized, is the best available analogue site. Climatic distance was computed using the equation proposed by Luedeling and Neufeldt (2012), which includes weighting and normalization factors:

$$
\text { climatic distance }=\sqrt{\sum_{p a r} \sum_{m} w_{p a r, m} \cdot\left(\frac{P_{p a r, m}-F_{p a r, m}}{n o r m_{p a r}}\right)^{2}},
$$

where:

par is the array of weather parameters

$m$ is the list of all months in the year

$w_{p a r, m}$ is a weighting factor for weather parameter and month, set in this case to 1 for temperature parameters and 2 for precipitation

$P_{p a r, m}$ is the value of the weather parameter par for month $m$ in the present scenario

$F_{p a r, m}$ is the value of the weather parameter par for month $m$ in the future scenario

norm $_{p a r}$ is a normalization parameter, set to the interquartile range of the distribution of the respective monthly values in the entire population of grid cells

Lacking evidence favoring one possible weighting scheme over others, selection of optimal values for weighting climate metrics was based on researcher experience. More emphasis (double weights) was placed on precipitation than temperature parameters, due to the common perception of rainfall being the primary determinant of a location's agricultural potential in this region.

Climate data used for the analogue analysis were derived from three global circulation models (GCMs), considering two greenhouse gas emissions scenarios and three future points in time. The three global climate models that were used in this study were the Canadian General Circulation Model 2 by the Canadian Centre for Climate Modeling and Analysis (CCCMA-CGCM2; Flato et al., 2000; Kim et al., 2003), the Hadley Center Coupled Model version 3 (HadCM3; Gordon et al., 2000; Singarayer \& Valdes, 2010) and the Commonwealth Scientific and Industrial Research Organization Atmospheric Research Mark 2b (CSIRO-Mk2; Hirst et al., 1999). Model projections were driven by two IPCC SRES greenhouse gas emissions scenarios (A2a and B2a; Nakicenovic et al., 2000), and analogues were determined for three future time horizons (2020s, 2050s and 2080s).

All data were obtained from the climate data portal of the CGIAR Research Program on Climate Change, Agriculture and Food Security (CCAFS, 2013), where projections downscaled to a resolution of 2.5 arc minutes ( $\sim .6 \mathrm{~km}$ in the study area) with the Delta method (Hijmans et al., 2005) were available. A baseline climate dataset, representing conditions between 1950 and 2000, was also obtained from this source. For all climate scenarios, mean precipitation, mean daily minimum temperature and mean daily maximum temperature were obtained for each month of the year, resulting in a total of 36 variables as the basis for the analogue search.

For field work, resources were only available for evaluating one baseline/analogue site pair. The A2a scenario was selected for this analysis, because it tracks past emissions of greenhouse gases more closely than the B2a scenario. As for time horizons, the 2050s were selected, because they constitute a reasonable planning horizon for adaptation studies (the 2020s were considered too close, the 2080s too far in the future). 


\subsection{Surveys}

Minor changes were made to a household questionnaire designed by the CCAFS program for evaluating adaptive capacity (Somé et al., 2011). This survey tool, which has widely been used in East and West Africa, as well as in South Asia, was slightly adapted for this study by the addition of questions on the use of manure and fallows, assets owned, breeds of animals, sources of information for the different agricultural techniques and main constraints to farming. The questionnaire contained qualitative and quantitative questions, both of the open-ended and closed-ended variety. The sections that were deemed important for assessing farming systems were those addressing livelihood security, crop, animal and land management, food security, land and water, inputs and credit and assets.

Questionnaires were administered by trained enumerators to 247 households in the target location in April 2012 and to 203 households in the analogue location in May 2013. The households were sampled using the stratified random sampling technique (Lehtonen \& Djerf, 2008). Households were sub-divided into two strata according to the administrative unit in which they were located. A number of households were then randomly selected from each zone. The number of households to be sampled was determined using the sample size calculator at a confidence level of $95 \%$ (Wimmer, 2001).

\subsection{Data Analysis}

All data were initially entered into the Census and Survey Processing System (CSPro) version 5.0 software (Population Division, U.S. Census Bureau, Washington, DC, U.S.A.) and then exported to the Statistical Package for Social Sciences (SPSS) version 17.0.1 (SPSS Inc., Chicago, IL, U.S.A.) where they were coded. To ensure reliability, double data entry was practiced. Descriptive statistics were then computed using SPSS 17.0.1.

\section{Results}

\subsection{Climate Analogues for Bugabira Commune}

The analogue search provided 18 potential analogue locations (Table 1). Climate analogues were distributed throughout different parts of Burundi, as well as in a small region at the border between Rwanda and Tanzania (Figure 1). For the combination of emissions scenario and time horizon that was targeted for further analysis, only one of the three candidate analogues (for the hccpr_hadcm3 climate model) was located in Burundi (Figure 1). The closest locality to the identified analogue site was Bubanza, a place 97 kilometers away from Bugabira and 39 kilometers northwest of Bujumbura, the country's capital. The projected climate of Bugabira closely resembles the current climate of Bubanza (Figure 2). Figure 1 also shows other analogue locations being closely scattered around Bubanza with the closest one being for the scenario hccpr_hadcm3 B2a 2050s.

The different potential analogues that resulted from the analysis meant that the location of climate analogues depended on the GCM used, the emissions scenario and the timeline under consideration (Hallegatte et al., 2007). There was no basis for focusing on only one 'best' analogue location, because it is typically assumed that none of the GCMs is clearly superior to the others. Variability among scenarios was not very high for the mid-century projections, as indicated by the proximity of all corresponding analogue sites. This indicated that Bugabira's future climate for the 2050s could be projected with some confidence and that for this time horizon, uncertainty arising from the choice of emissions scenario was relatively small (Hawkins \& Sutton, 2009). However, with increased global warming the analogues could be very far apart (Kopf et al., 2008), thus increasing uncertainty for late-century projections. 
Table 1. Closest climate analogue locations of Bugabira (Baseline) for three global circulation models, two greenhouse gas emissions scenarios and three time horizons

\begin{tabular}{llllll}
\hline Year & Global Circulation Model & Greenhouse Gas Emissions Scenario & Latitude & Longitude \\
\hline 2000 & Baseline & None & -2.60 & 30.10 \\
1. & $2020 \mathrm{~s}$ & cccma_cgcm2 & B2a & -2.77 & 29.85 \\
2. & $2020 \mathrm{~s}$ & csiro_mk2 & B2a & -1.98 & 30.85 \\
3. & $2020 \mathrm{~s}$ & hccpr_hadcm3 & B2a & -2.02 & 30.94 \\
4. & $2050 \mathrm{~s}$ & cccma_cgcm2 & B2a & -2.77 & 29.15 \\
5. & $2050 \mathrm{~s}$ & csiro_mk2 & B2a & -2.77 & 29.10 \\
6. & $2050 \mathrm{~s}$ & hccpr_hadcm3 & B2a & -2.85 & 29.19 \\
7. & $2080 \mathrm{~s}$ & cccma_cgcm2 & B2a & -2.77 & 29.10 \\
8. & $2080 \mathrm{~s}$ & csiro_mk2 & B2a & -2.81 & 29.10 \\
9. & $2080 \mathrm{~s}$ & hccpr_hadcm3 & B2a & -2.98 & 29.27 \\
10. & $2020 \mathrm{~s}$ & cccma_cgcm2 & A2a & -2.56 & 29.94 \\
11. & $2020 \mathrm{~s}$ & csiro_mk2 & A2a & -2.44 & 30.10 \\
12. & $2020 \mathrm{~s}$ & hccpr_hadcm3 & A2a & -2.02 & 30.85 \\
13. & $2050 \mathrm{~s}$ & cccma_cgcm2 & A2a & -2.73 & 29.10 \\
14. & $2050 \mathrm{~s}$ & csiro_mk2 & A2a & -2.77 & 29.10 \\
15. & $2050 \mathrm{~s}$ & hccpr_hadcm3 & A2a & -2.94 & 29.27 \\
16. & $2080 \mathrm{~s}$ & cccma_cgcm2 & A2a & -2.85 & 29.10 \\
17. & $2080 \mathrm{~s}$ & csiro_mk2 & A2a & -2.98 & 29.27 \\
18. & $2080 \mathrm{~s}$ & hccpr_hadcm3 & A2a & -3.06 & 29.35 \\
\hline
\end{tabular}

Cccma_cgcm2 is the Canadian Centre Model, csiro_mk2 is the Commonwealth Scientific and Industrial Research Organization model, hccpr_hadcm3 is the Hadley Center Coupled model and "baseline" means the actual conditions at the target location in the year 2000, representing the twentieth century climate. 


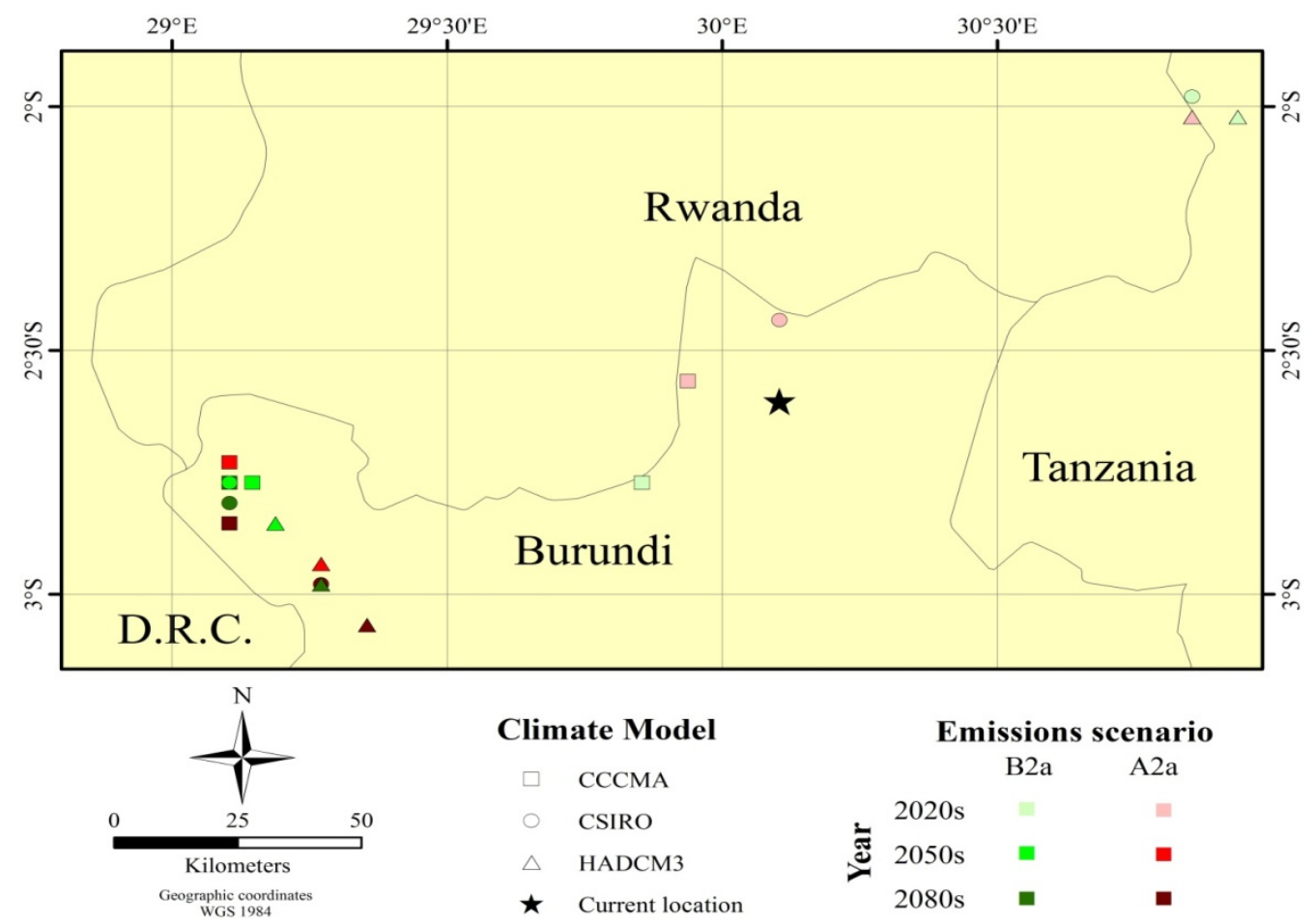

Figure 1. Climate analogue locations of Bugabira, Kirundo, Burundi, according to three general circulation models (HadCM3, MK2 and CGCM2), two greenhouse gas emissions scenarios (A2a and B2a) and for three time horizons (2020s, 2050s and 2080s)

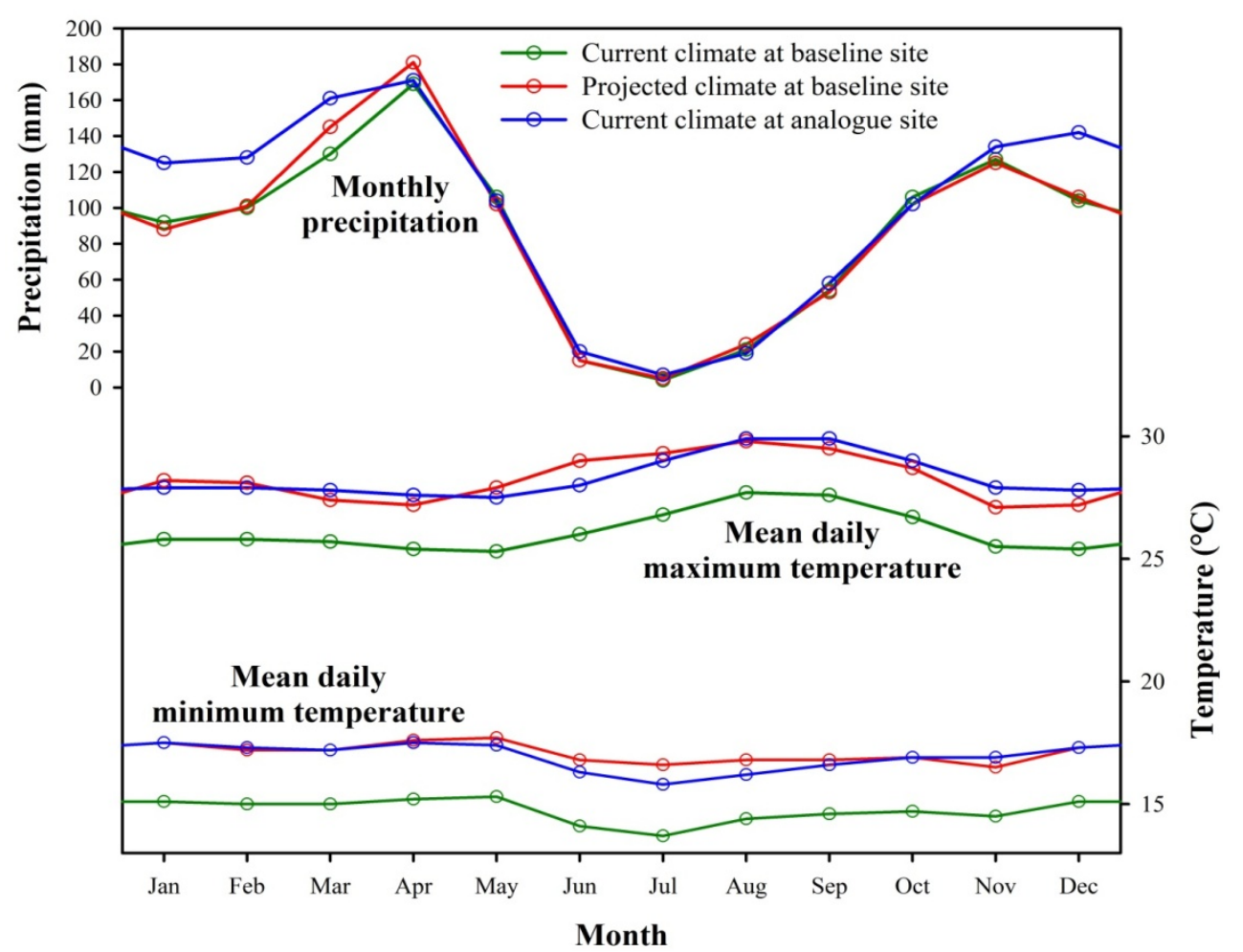

Figure 2. Comparison of climatic parameters in the two locations, i.e. the current (green line) and projected (red line) climate for Bugabira, the target site, and the current climate of Bubanza, the closest analogue location for the 2050s according to the hccpr_hadcm 3 climate model for the A2a emissions scenario (blue line) 
Bubanza Commune, the analogue used for this study, is located at approximately $3.1^{\circ} \mathrm{S}$ latitude and $29.4^{\circ} \mathrm{E}$ longitude. It covers an area of about $225 \mathrm{~km}^{2}$ with an average altitude of $1500 \mathrm{~m}$. It has a population of about 83,678 inhabitants. The commune's climate is that of a tropical savanna, which experiences two main seasons; the wet season runs from September to April, while the dry season runs from May to August. The area is characterized by rainfall averages of between 1200-1500 mm and a temperature range of between 20 and $27^{\circ} \mathrm{C}$. In terms of hydrology, the Mpanda and Kajeke Rivers and several smaller rivers such as Kidahwe, Nyaburiga, Kadakamwa and Nyakabingo pass through the commune. The most common natural vegetation type is savanna, which consists of a discontinuous crown cover of trees and shrubs and an undergrowth of grasses (Okitsu, 2005). Soils are lateritic, indicating that they are highly weathered soils with high iron content and low organic matter concentrations. Common crops include bananas, cassava, sweet potatoes, beans, maize and rice.

\subsection{Comparison Between Farming Systems in Bugabira and Bubanza}

Farmers in both locations grow crops and raise livestock on small pieces of land. Land size per household was highly varied with the median farm size being 1.33 ha for Bugabira and 0.85 ha for Bubanza. Farming was largely rainfed, with $25 \%$ of farmers in each location practicing irrigation with small containers. Most of the land was cultivated with food crops. Crops grown included beans, sweet potatoes, cassava and maize (Figure 3). There was little cultivation of cash crops in the analogue location, with the exception of rice.

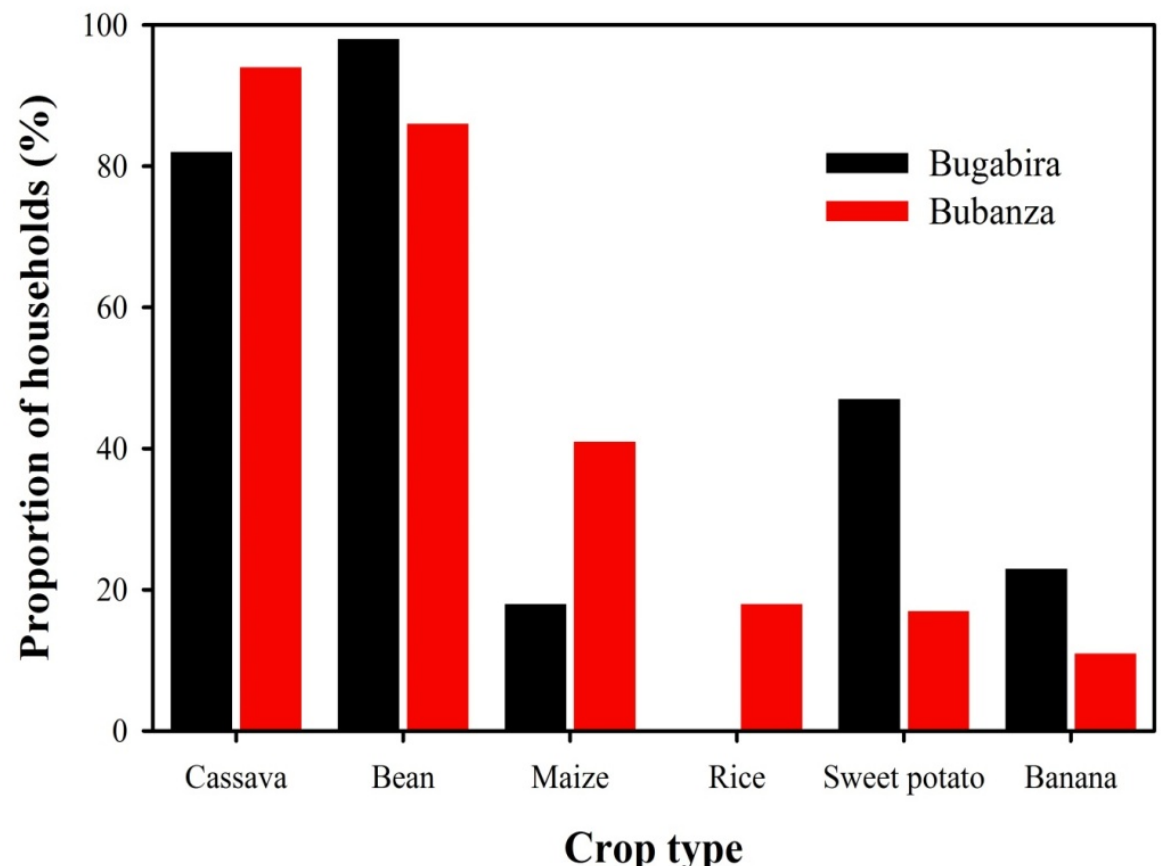

Figure 3. Distribution of common crop types among households in Bugabira (Baseline, black bars) and Bubanza (Analogue, red bars)

Animals kept included goats, cows, chicken and pigs (Figure 4). More farmers kept cattle in Bugabira (30\%), the target, than in Bubanza (12\%), while chicken and pigs were kept by more farmers in Bubanza $(38 \%$ and $27 \%$ respectively), the analogue, than in Bugabira (22\% and $11 \%$ respectively). 


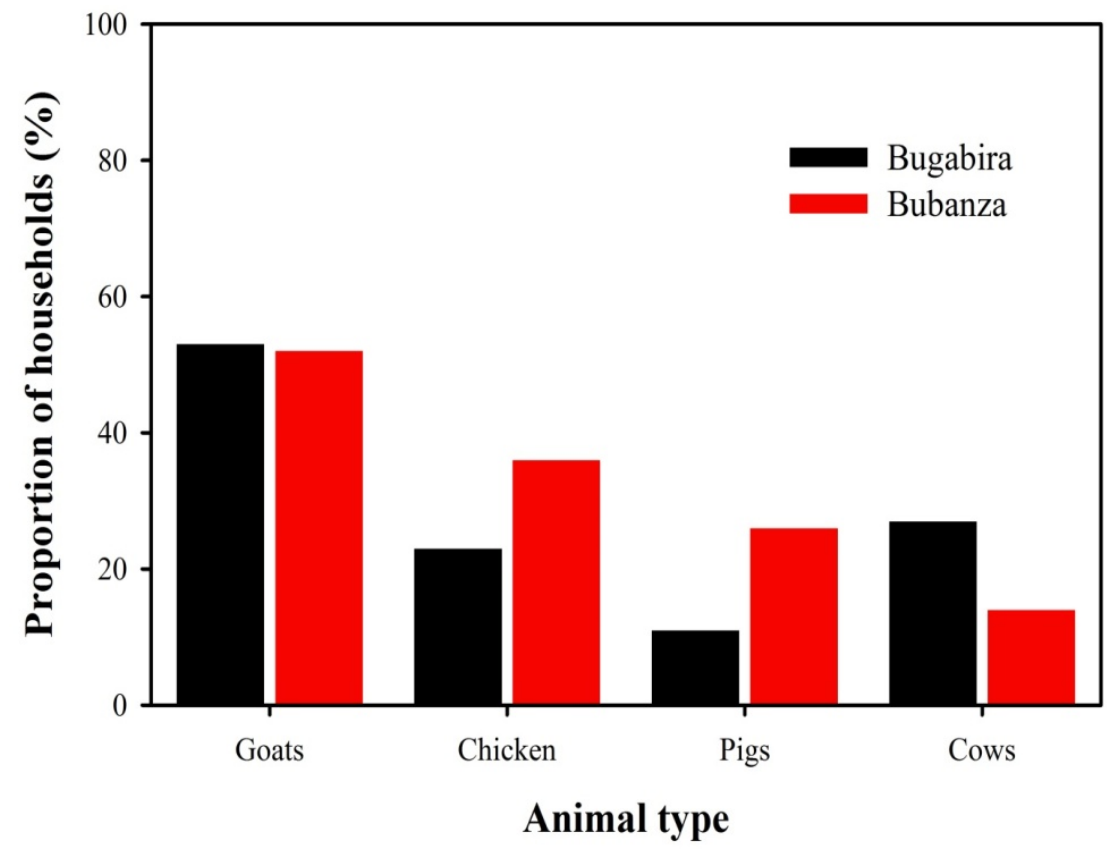

Figure 4. Distribution of common animal types among households in Bugabira (Baseline, black bars) and Bubanza (Analogue, red bars)

Forty-seven percent of farmers in Bugabira and 37\% of farmers in Bubanza had stopped keeping certain animals, most often cows, in the last 10 years. Fodder growing was practiced by $63 \%$ of farmers in Bugabira and $10 \%$ of farmers in Bubanza. Both locations practiced small-scale agroforestry of mainly fruit trees. Some of the technologies adopted were irrigation, composting and use of improved varieties (Table 2). Chemical fertilizers, especially Diammonium Phosphate (DAP) and urea, were used by more households in Bubanza (37\%) than in Bugabira (10\%). The fertilizers were applied mainly to rice, maize and vegetables. Sources of cash income for households in both locations were employment on other people's farms, income from small businesses, loans and the sale of products from both on and off-farm sources. Products sold included food crops, processed food, vegetables, fruits, small livestock, fodder and timber. The main constraints that farmers faced were limited availability or access to inputs such as fertilizers, improved seed, labour and capital. In addition to these, drought and unpredictable weather were also a problem for the farmers, especially in the target location. In the analogue location diseases were also mentioned as one of the constraints to agricultural production. Some practices were used in both communes, namely intercropping, rotational cropping, contour ploughing, use of manure and early/delayed planting. While $87 \%$ of farmers in Bugabira used manure, only $58 \%$ in Bubanza did so. Seventy-four percent of farmers in Bugabira and $55 \%$ in Bubanza grew better quality varieties. Seventy-two percent and $48 \%$ grew drought-tolerant varieties and $86 \%$ and $68 \%$ grew disease-resistant varieties in Bugabira and Bubanza, respectively. In all cases, the proportion of households carrying out the practices was higher in Bugabira than in Bubanza. Some other practices, such as built ridges were only used by a few households in Bubanza (11\%). 
Table 2. Proportion of farmers that made changes to crop and animal management practices in the last 10 years in Bugabira and Bubanza

\begin{tabular}{lll}
\hline Management of crops and animals & \% households in Bugabira & \% households in Bubanza \\
\hline Introducing new animals & 56 & 47 \\
Introducing new breeds & 16 & 4 \\
Testing new animals & 34 & 22 \\
Increasing herd size & 10 & 6 \\
Reducing herd size & 18 & 10 \\
Stopped keeping animals & 47 & 37 \\
Cut and carry systems & 31 & 5 \\
Growing fodder & 63 & 10 \\
Growing improved pastures & 11 & 3 \\
Growing higher yielding variety & 68 & 70 \\
Growing better quality variety & 74 & 55 \\
Testing new crop & 61 & 23 \\
Testing a new variety & 55 & 25 \\
Introduced new crop & 85 & 46 \\
Drought-tolerant variety & 72 & 48 \\
Disease-resistant variety & 86 & 68 \\
Flood-tolerant variety & 53 & 35 \\
Pest-resistant variety & 38 & 24 \\
Introduced irrigation & 9 & 13 \\
\hline
\end{tabular}


Table 3. Characteristics of farming systems at Bugabira and Bubanza compiled from household surveys

\begin{tabular}{l}
\hline Comparison between systems \\
\hline Climate and environment \\
- $\quad$ Presence of fruit trees \\
- $\quad$ Most land under \\
cultivation, no \\
communal grazing land \\
- $\quad$ Swamps in valleys \\
- Two growing seasons \\
- Smaller variation/range \\
of average annual \\
rainfall and temperature \\
as well as altitude.
\end{tabular}

Crop production and agronomic practices

- Rainfed crop production

- Main staple crops-beans, cassava, sweet potato

Yes

Bugabira farming system

Bubanza farming system

Wider variation/range of average annual rainfall and temperature as well as altitude

Yes

- Desire to use improved seeds

- Sale of surplus

- Low use of farm inputs

- Use of manure

\section{Livestock production}

- Small-scale agroforestry

- Small-scale livestock Yes production, mainly goats, cattle and poultry

Yes

Yes

With maize as third important instead of sweet potato

Yes

Pigs are more important than cattle

Yes

- Drought

- High price of inputs

- Lack of improved seed

- Inadequate land
- Unpredictable weather

- High price of inputs

- Diseases

- Lack of improved seed

- Low fertility soils 


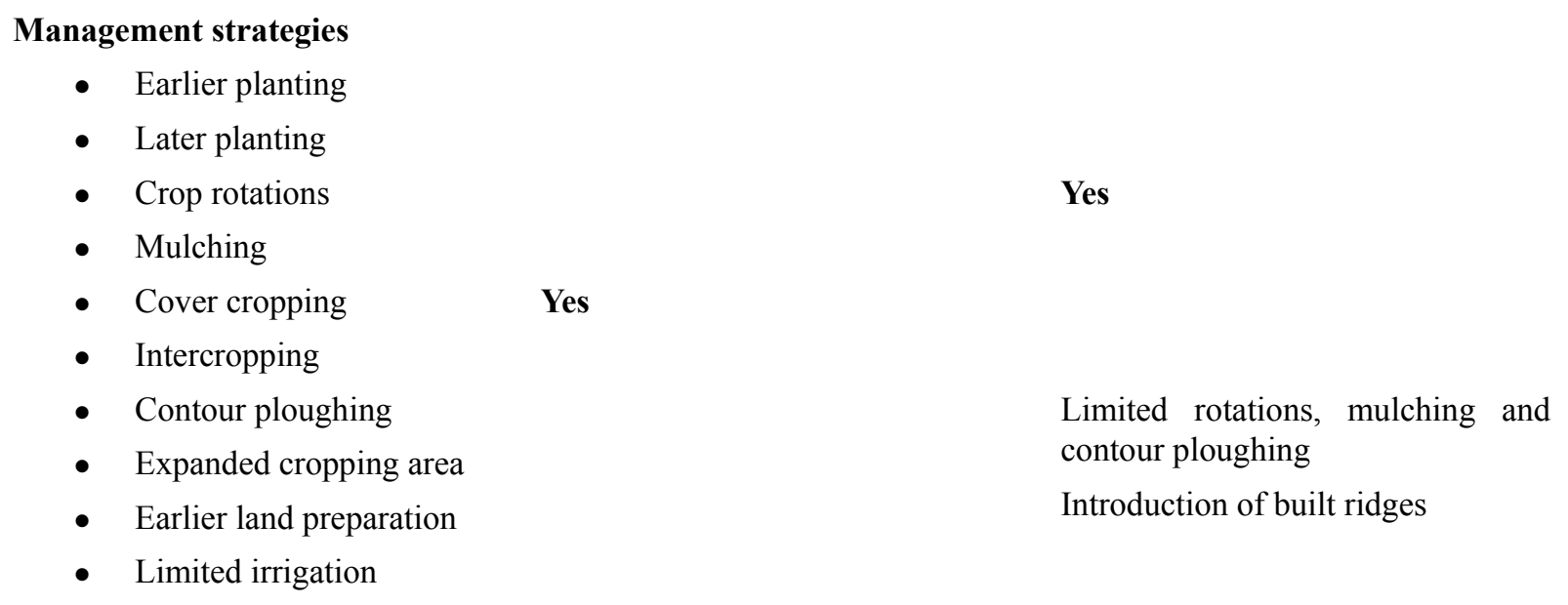

Yes denotes that the practices occur in the area.

\section{Discussion}

\subsection{Identification of Analogue Locations}

Reasonably close climate analogues were found for all climate scenarios. None of them were in the same location as the study site, indicating that the future climate at the site of interest resembles the current climate elsewhere more closely than the current climate at the site itself (Kopf et al., 2008). The analogues tended to be further away from the target location for late-century projections (Hawkins \& Sutton, 2009). If one were to follow best practices of climate impact analysis, visits to all climate analogue locations would be necessary, so that the range of plausible climate futures could be captured in a scenario ensemble approach. For climate analogues, however, such coverage is rarely possible because each site visit incurs substantial costs, especially if in-depth surveys are conducted at each location (Akbayrak, 2000). This constraint limits the number of analogues that can be compared with the baseline site. In our case, only one site could be visited, raising concerns about the representativeness of the selected climate scenario. However, such concerns are likely to apply to the majority of practical applications of the climate analogue approach, because there will rarely be sufficient resources to undertake a full ensemble analysis. For the method to retain one of its major advantages that it is faster and cheaper than model-based approaches - the number of locations that can be analyzed has to be fairly low. Our comparison of two sites therefore represents a useful test of the approach under conditions likely to apply in practice.

\subsection{Characteristics of Farming Systems at Bugabira and Bubanza}

The farming systems of both locations were mixed smallholder systems. Systems were composed of crop production activities, livestock production activities and off-farm livelihood activities. The higher number of farmers that use fertilizers in Bubanza compared to Bugabira could be due to infertile soils there, which were mentioned as one of the constraints to farming. The lateritic soils present in Bubanza, the analogue, tend to be acidic, have high aluminum levels and exhibit a propensity to form hard crusts. Farm products are only sold after the household needs have been fulfilled. Crops grown in both communes were somewhat drought-resistant varieties with multiple benefits, especially cassava. Battisti and Naylor (2009) noted that crops tolerant to drought and heat will gain demand in a world that is becoming hotter and possibly drier due to climate change. Beans, a major staple of Eastern and Southern Africa, tend to be drought-tolerant (Broughton et al., 2003) and also offer a cheap source of protein, their stems can be used as livestock feed and they contribute to restoration of soil fertility through nitrogen fixation (Rondon et al., 2006). In Rwanda and Burundi, statistics show that the average national consumption of beans exceeds $40 \mathrm{~kg}$ per person per year (Broughton et al., 2003). Cassava can tolerate drought through actions such as leaf fall, partial closure of stomata and deep root penetration into soil to access water (Okogbenin et al., 2013). Cassava can be grown with minimal inputs and has the ability to recover from biotic and abiotic stresses (Burns et al., 2010). In addition, it has a higher yield potential than maize and rice, and it can be used for both human and animal consumption (Scott et al., 2000). Maize, being a C4 plant, is an efficient user of water and thus better adapted than $\mathrm{C} 3$ plants to environments with high daytime temperatures, intense sunlight and drought (Crafts-Brandner \& Salvucci, 2002).

Crop diversification in the two locations appeared to constitute a risk reduction response to changing weather 
patterns, as has also been documented by Thomas et al. (2007). Goat-keeping and introduction of pigs was probably because these animals are known to be hardy and they are much easier to keep and feed than cows. Eighty-eight percent of farmers in Bubanza (analogue) and 70\% of farmers in Bugabira (baseline) do not keep cattle. Kurukulasuriya and Mendelsohn (2007) analysed crop and livestock choices as climate change adaptation options and found that farmers in warm climates tend to choose goats and sheep as opposed to cattle and chicken. Goats are more versatile in their feeding behaviour as they prefer browsing rather than grazing and are known as intermediate feeders between grazing and browsing (Silanikove, 1997; Fisher, 2002). Intermediate feeders change their feeding habits according to availability of forage and usually they eat immature grasses; as the forage matures they move on to browsing behaviour (Peter, 1994). Goats are opportunistic mixed feeders (Hofmann, 1989) and therefore suited for resource scarce areas, because of their ability to adapt to changes in forage quality.

There was a high level of diversity in both communes with new crop varieties and animal breeds being introduced and modern methods of farming being integrated as was also found by Dixon et al. (2014) in his study on farming systems in Uganda. The sale of food crops and non-food items as well as other off-farm activities to generate income were present in both communes. Some innovative practices, such as the use of drought-tolerant varieties, irrigation measures, sale of livestock and introduction of new animal types, were indicative of climate being a factor affecting farmers' decisions. The introductions of built ridges and micro catchments in Bubanza (analogue) were seen as specific responses to variable rainfall conditions, since these structures are used to retain water for crop growth and also to control soil erosion (Thomas et al., 2007). Some practices that were used by more households in the target than the analogue location, such as contour ploughing and mulching, aim to enhance infiltration and control erosion and could be interpreted as a response to climate. On the other hand, their introduction may also be motivated by other reasons, such as improving soil fertility, that are not necessarily related to climate.

The practices employed indicated that farmers may be considering climatic factors to some extent when making adjustments in their farming practices, but their behavior seemed to be driven more strongly by market factors. Major constraints faced by farmers in both locations were climate variability and limited access to production factors. This was in agreement with Mubaya et al. (2012) who highlighted that farmers are generally affected by similar factors relating to lack of inputs, capital, labour and climate.

Distinguishing between adaptation actions and routine actions that aimed at increasing resilience to climate variability was difficult, as was also noted by Findlater (2013). In general, land management activities were seen as strategies to improve production - results which agree with those of Thomas et al. (2007). Some of the strategies employed included crop selection, diversification, changing planting dates, adopting relevant technologies and selling animals. The sale of animals was seen as a last resort in dry periods.

\subsection{Climate Analogues as a Conceptual Framework for Adaptation Planning}

Results that emerged from the site comparison were inconclusive, with no emergence of clear recommendations for adaptation. Target and analogue sites were very similar, and the few differences that existed could not unambiguously be attributed to differences in climate. They were just as likely - if not more likely - to have arisen from non-climatic factors that differed between locations. These could, for instance, be related to market access or local traditions. In principle, some such factors could be included in the analogue search procedure (Horvath, 2008; Adger et al., 2003). Especially for some aspects of the biophysical environment, such as soil type, slope etc., this might be feasible, even though appropriate datasets at adequate resolution are often difficult to obtain. Such inclusion would raise questions about appropriate weighting schemes and adequate methods for including categorical data (e.g. soil type) into the climatic distance calculation, but such challenges could probably be overcome. Yet even if some non-climatic data were included, it seems unlikely that these data could be exhaustive enough to cover all relevant factors. In particular for socioeconomic variables, information is normally unavailable, especially when considering that such data cannot be limited to a few locations only. They would have to be available in gridded format and cover the entire region, in which the analogue search is conducted.

If it is impossible to control for all non-climatic factors, it will always be challenging to clearly identify those differences between sites that are attributable to climate and thus constitute promising adaptation options for the target site. Especially in Sub-Saharan Africa, cropping systems respond to a large number of environmental, socioeconomic (ILRI, 2012) and political drivers, including - besides climate - chemical, physical and biological soil properties (Folberth et al., 2012), water availability, topography, land tenure, market access (Poulton et al., 2006; OECD, 2006), labor availability (Blair-Rains, 1986), pest, disease and weed pressure, access to information, livestock density, activities by extension services or other development actors, 
government programs or regulations etc. Many of these differ so strongly between locations that slight differences in temperature or precipitation of the magnitude that climate change is expected to bring about over the $21^{\text {st }}$ century may be of relatively small significance. It may then often be the case that for the best possible climate analogue, non-climatic site conditions are so different that practices cannot easily be transferred from the analogue to the target site (Leterme et al., 2012). In fact, caution must be applied in attributing any differences between sites to climate, because they may have been caused by numerous other factors. In this light, adaptation strategies derived from analogue analysis should be carefully scrutinized for their local appropriateness to avoid promotion of technologies that work in the kind of climate that is expected in the future but may not be suitable for the socio-ecological system at the target site.

\section{Conclusion}

The climate analogue location that was selected for Bugabira was Bubanza, a location within Burundi, 97 kilometers away from Bugabira, the target location. A number of other potential analogues were found in close proximity, indicating that the selection of the climate scenario did not cause large differences in locating analogues.

Climate characteristics of the two locations were not very different, leading to largely similar crop and livestock production systems and sources of livelihood. Reasons given for changes made to practices in both locations tended to be similar, meaning that most of the concerns faced by farmers at the analogue location were also experienced at the target site. However, climatic issues such as drought, delayed onset of rains and erratic rainfall were of concern to more households in the target than the analogue location. Overall, the agronomic practices in both locations were aimed at improving soil quality and enhancing water conservation for improved production. The two farming systems were not very different thus implying that the target location may not need to change much in the future in order to adapt to its projected climate.

None of the differences between the target and analogue location could clearly be attributed to climatic differences and therefore recommended as adaptation strategies for the target site. Even though some differences existed, these may have arisen from a number of non-climatic factors, such as market access, cultural traditions or promotion of particular technologies by government or other development agents. We suspect that in most agricultural systems climate differences of the magnitude that is projected by climate models have a weaker effect on system properties than differences in a number of other factors. It may then be unwise to promote agricultural techniques observed at an analogue location at the target site, without a thorough assessment of its suitability there. In light of these considerations, the potential of the climate analogue approach for adaptation planning appears quite limited. While it may provide interesting ideas for adaptation, analogue analysis is unlikely to deliver ready-made solutions that can directly be applied at the target site. The high degree of randomness caused by the probably inevitable necessity to narrow the comparison to only a small number of sites casts severe doubts on the suitability of the analogue approach as a general framework for adaptation planning.

\section{Acknowledgement}

The authors are indebted to all farmers who participated in this study, as well as to The Institut des Sciences Agronomiques du Burundi (ISABU) for logistic support. We acknowledge support from Concern Worldwide Burundi, as well as from the CGIAR Research Programs on 'Climate Change, Agriculture and Food Security' (CCAFS), 'Water, Land and Ecosystems' (WLE) and 'Forests, Trees and Agroforestry' (FTA).

\section{References}

Adger, W. N., Huq, S., Brown, K., Conway, D., \& Hulme, M. (2003). Adaptation to climate change in the developing world. Progress in Development Studies, 3(3), 179-195. http://dx.doi.org/10.1191/1464993403ps060oa

Akbayrak, B. (2000). A comparison of two data collecting methods: interviews and questionnaires. European Journal of Education, 18(1), 1-10. Retrieved from www.efdergi.hacettepe.edu.tr/200018BURCU AKBAYRAK.pdf

Antwi-Agyei, P., Dougill, A. J., Lindsay, C., \& No, W. P. (2013). Barriers to climate change adaptation in subSaharan Africa : evidence from northeast Ghana \& systematic literature review. Centre for Climate Change Economics and Policy.

Arnbjerg-Nielsen, K. (2012). Quantification of climate change effects on extreme precipitation used for high resolution hydrologic design. Urban Water Journal, 9(2), 57-65. http://dx.doi.org/10.1080/1573062X.2011.630091 
Battisti, D., \& Naylor, R. (2009). Historical warnings of future food insecurity with unprecedented seasonal heat. Science, 323(January), 240-244. http://dx.doi.org/10.1126/science.1164363

Blair-Rains, A. (1986). Soil-related constraints in major farming systems of agro-ecological zones of sub-Saharan Africa. Food and Agriculture Organization of the United Nations. Retrieved August 27, 2014, from http://www.fao.org/wairdocs/ilir//x5488e/x5488e05.htm

Braconnot, B., Gillett, N. P., Marengo, J. A., Luo, Y., \& Al, E. (2007). Understanding and Attributing Climate Change. IPCC WGR1 AR4 (pp. 665-744).

Broughton, W. J., Hern, G., Blair, M., Beebe, S., Gepts, P., \& Vanderleyden, J. (2003). Beans ( Phaseolus spp .) - model food legumes. Plant and Soil, 252, 55-128. http://dx.doi.org/10.1023/A:1024146710611

Burke, M. B., Lobell, D. B., \& Guarino, L. (2009). Shifts in African crop climates by 2050, and the implications for crop improvement and genetic resources conservation. Global Environmental Change, 19(3), 317-325. http://dx.doi.org/10.1016/j.gloenvcha.2009.04.003

Burns, A., Gleadow, R., Cliff, J., Zacarias, A., \& Cavagnaro, T. (2010). Cassava: The Drought, War and Famine Crop in a Changing World. Sustainability, 2(11), 3572-3607. http://dx.doi.org/10.3390/su2113572

Butterfield, R., Dyszynski, J., Watkiss, P., \& Downing, T. (2011). Economics of Adaptation: The Economic Impacts of Climate Change in Burundi. weADAPT.

Calzadilla, A., Rehdanz, K., Betts, R., Falloon, P., Wiltshire, A., \& Tol, R. S. J. (2013). Climate change impacts on global agriculture. Climatic Change, 120(1-2), 357-374. http://dx.doi.org/10.1007/s10584-013-0822-4

CCAFS. (2013). Data- Climate Change, Agriculture and Food Security. Retrieved from http://www.ccafs-climate.org/data/

Challinor, A. J., Wheeler, T. R., Craufurd, P. Q., Slingo, J. M., \& Grimes, D. I. F. (2004). Design and optimisation of a large-area process-based model for annual crops. Agricultural and Forest Meteorology, 124(1-2), 99-120. http://dx.doi.org/10.1016/j.agrformet.2004.01.002

Challinor, A., Wheeler, T., Garforth, C., Craufurd, P., \& Kassam, A. (2007). Assessing the vulnerability of food crop systems in Africa to climate change. Climatic Change, 83(3), 381-399. http://dx.doi.org/10.1007/s10584-007-9249-0

Challinor, A. J., Osborne, T., Shaffrey, L., Weller, H., Morse, A., Wheeler, T., \& Vidale, P. L. (2009). Methods and Resources for Climate Impacts Research. Bulletin of the American Meteorological Society, 90(6), 836-848. http://dx.doi.org/10.1175/2008BAMS2403.1

Crafts-brandner, S. J., \& Salvucci, M. E. (2002). Sensitivity of Photosynthesis in a C4 Plant, Maize, to Heat Stress. Plant Physiology, 129(4), 1773-1780. http://dx.doi.org/10.1104/pp.002170

CRED. (2009). Result Disaster Profiles, Emergency Events Database (EM-DAT). The International Disaster Database: Centre for Research on the Epidemiology of Diseases. Retrieved from http://www.emdat.be/database

CSIRO-ACLEP. (2006). ASC - ORGANOSOLS. The Australian Soil Classification. The Commonwealth Scientific and Industrial Research Organization and the Australian Collaborative Land Evaluation Program. Retrieved from www.clw.csiro.au/aclep/

Dixon, J., Stringer, L., \& Challinor, A. (2014). Farming System Evolution and Adaptive Capacity: Insights for Adaptation Support. Resources, 3(1), 182-214. http://dx.doi.org/10.3390/resources3010182

FAO. (1988). FAO/Unesco Soil Map of the World. Wageningen: International Soil Reference and Information Centre. Retrieved from http://www.fao.org/fileadmin/user_upload/soils/docs/isricu_i9264_001.pdf

Findlater, K. (2013). The complexities of climate change adaptation in South African agriculture. Africa Portal.

Fisher, D. S. (2002). A Review of a Few Key Factors Regulating Voluntary Feed Intake in Ruminants. Crop Science, 1655(May 2001), 1651-1655.

Flato, G. M., Boer, G. J., Lee, W. G., McFarlane, N. a., Ramsden, D., Reader, M. C., \& Weaver, A. J. (2000). The Canadian Centre for Climate Modelling and Analysis global coupled model and its climate. Climate Dynamics, 16(6), 451-467. http://dx.doi.org/10.1007/s003820050339

Folberth, C., Gaiser, T., Abbaspour, K. C., Schulin, R., \& Yang, H. (2012). Regionalization of a large-scale crop growth model for sub-Saharan Africa: Model setup, evaluation, and estimation of maize yields. Agriculture, Ecosystems \& Environment, 151, 21-33. http://dx.doi.org/10.1016/j.agee.2012.01.026 
Gordon, C., Cooper, C., Senior, C. A., Banks, H., Gregory, J. M., Johns, T. C., B., M. J. F., et al. (2000). The simulation of SST, sea ice extents and ocean heat transports in a version of the Hadley Centre coupled model without flux adjustments. Climate Dynamics, 16, 147-168. http://dx.doi.org/10.1007/s003820050010

Hallegatte, S., Hourcade, J.-C., \& Ambrosi, P. (2007). Using climate analogues for assessing climate change economic impacts in urban areas. Climatic Change, 82(1-2), 47-60. http://dx.doi.org/10.1007/s10584-006-9161-z

Hawkins, E., \& Sutton, R. (2009). The Potential to Narrow Uncertainty in Regional Climate Predictions. Bulletin of the American Meteorological Society, 90(8), 1095-1107. http://dx.doi.org/10.1175/2009BAMS2607.1

Hijmans, R. J., Cameron, S. E., Parra, J. L., Jones, P. G., \& Jarvis, A. (2005). Very high resolution interpolated climate surfaces for global land areas. International Journal of Climatology, 25(15), 1965-1978. http://dx.doi.org/10.1002/joc.1276

Hijmans, R. J., \& Graham, C. H. (2006). The ability of climate envelope models to predict the effect of climate change on species distributions. Global Change Biology, 12(12), 2272-2281. http://dx.doi.org/10.1111/j.1365-2486.2006.01256.x

Hirst, A., SP, O., \& HP, G. (1999). Comparison of a Coupled Ocean - Atmosphere Model with and without Oceanic Eddy-Induced Advection . Part I : Ocean Spinup and Control Integrations. Journal of Climate, 13(1), 139-163. http://dx.doi.org/10.1175/1520-0442(2000)013\%3C0139:COACOA\%3E2.0.CO;2

Hofmann, R. R. (1989). Evolutionary Steps of Ecophysiological Adaptation and Diversification of Ruminants: A Comparative View of their Digestive System. Oecologia, 78(4), 443-457. http://dx.doi.org/10.1007/BF00378733

Horvath, L. (2008). Use of the spatial analogy method to analyse to possible landuse change in Hungary. World conference on agricultural information, 209-213.

ILRI. (2012). Drivers of change in crop-livestock systems and their potential impacts on agro-ecosystems services and human wellbeing to 2030 (p. 6). Nairobi. Retrieved from https://cgspace.cgiar.org/bitstream/handle/10568/3020/SLP drivers study final draft.pdf?sequence=4

IMF. (2012). International Monetary Fund country report. Republic of Burundi: Poverty reduction strategy paper II (pp. 1-155). Washington D.C. Retrieved from http://www.imf.org

ISTEEBU. (2014). GeoHive - Burundi population statistics. Population and area-Institut de Statistiques et d'Etudes Economiques $d u$ Burundi Bujumbura, Burundi. Retrieved from http://www.geohive.com/cntry/burundi.aspx

Kellet, J., Ness, D., Hamilton, C., Pullen, S., \& Leditschke, A. (2011). Learning from Regional Climate Analogues (p. 166). Gold Coast.

Kim, J., Flato, M., \& Boer, J. (2003). A coupled climate model simulation of the Last Glacial Maximum, Part 2 : approach to equilibrium. Climate Dynamics, 20, 635-661.

Kopf, S., Hallegatte, S., \& Ha-Duong, M. (2008). Using maps of city analogues to display and interpret climate change scenarios and their uncertainty. Natural hazards and earth system sciences, 8(2007), 905-918.

Kurukulasuriya, P., \& Mendelsohn, R. (2007). Crop Selection: Adapting to Climage Change in Africa.

Lehtonen, R., \& Djerf, K. (2008). Survey sampling reference guidelines - Introduction to sample design and estimation techniques. eurostat.

Leterme, B., Mallants, D., \& Jacques, D. (2012). Sensitivity of groundwater recharge using climatic analogues and HYDRUS-1D. Hydrology and Earth System Sciences, 16(8), 2485-2497. http://dx.doi.org/10.5194/hess-16-2485-2012

Lobell, D. B., \& Burke, M. B. (2008). Why are agricultural impacts of climate change so uncertain? The importance of temperature relative to precipitation. Environmental Research Letters, 3(3), 034007. http://dx.doi.org/10.1088/1748-9326/3/3/034007

Lobell, D. B., \& Burke, M. B. (2010). On the use of statistical models to predict crop yield responses to climate $\begin{array}{llll}\text { change. Agricultural and Forest Meteorology, 150(11), 1443-1452. } & \end{array}$ http://dx.doi.org/10.1016/j.agrformet.2010.07.008

Luedeling, E., \& Neufeldt, H. (2012). Carbon sequestration potential of parkland agroforestry in the Sahel. Climatic Change, 115(3-4), 443-461. http://dx.doi.org/10.1007/s10584-012-0438-0 
Luedeling, E., Muthuri, C., \& Kindt, R. (2013). Ecosystem vulnerability to climate change. World Agroforestry Centre, (Working Paper 162).

Meehl, G. A, Washington, W. M., Collins, W. D., Arblaster, J. M., Hu, A., Buja, L. E., Strand, W. G., et al. (2005). How much more global warming and sea level rise? Science (New York, N.Y.), 307(5716), 1769-72. http://dx.doi.org/10.1126/science.1106663

Millar, C. I., Stephenson, N. L., \& Stephens, S. L. (2007). Climate change and forests of the future: managing in the face of uncertainty. Ecological applications : a publication of the Ecological Society of America, 17(8), 2145-51. Retrieved from http://www.ncbi.nlm.nih.gov/pubmed/18213958

MINAGRIE. (2012). Ministere de l'Agriculture et de l'Elevage: Global Agriculture and Food Security Program, Burundi (pp. 1-28). Retrieved from www.burundi-gov.bi/minagrie

Minani, B., Rurema, D.-G., \& Lebailly, P. (2013). Rural resilience and the role of social capital of Kirundo Province farmers in North Burundi. Ngozi.

MINATTE. (2007). National Adaptation Plan of Action to climate change. Ministry of land management, tourism and environment (pp. 1-74). Bujumbura.

Mubaya, C. P., Njuki, J., Mutsvangwa, E. P., Mugabe, F. T., \& Nanja, D. (2012). Climate variability and change or multiple stressors? Farmer perceptions regarding threats to livelihoods in Zimbabwe and Zambia. Journal of environmental management, 102, 9-17. http://dx.doi.org/10.1016/j.jenvman.2012.02.005

Müller, C., Bondeau, A., Popp, A., \& Waha, K. (2010). Climate Change impacts on agricultural yields. World Development Report background note (pp. 1-11).

Müller, C., Cramer, W., Hare, W. L., \& Lotze-Campen, H. (2011). Climate change risks for African agriculture. Proceedings of the National Academy of Sciences of the United States of America, 108(11), 4313-5.

Muñoz, A.-R., Márquez, A. L., \& Real, R. (2013). Updating known distribution models for forecasting climate change impact on endangered species. PloS one, 8(6), e65462. http://dx.doi.org/10.1371/journal.pone.0065462

Nakicenovic, N., Ogunlade, D., Davis, G., Grubler, A., Kram, T., \& Al, E. (2000). Special report of working group III on emission scenarios. Summary for Policymakers (pp. 1-27).

Nelson, G. C., Rosegrant, M. W., Koo, J., Robertson, R., Sulser, T., Zhu, T., Ringler, C., et al. (2009). Climate Change Impact on Agriculture and Costs of Adaptation. International Food Policy Research Institute, (September), 1-19.

OECD. (2006). External constraints to agricultural development in Sub-Saharan Africa. Paris: African Development Bank. Retrieved from http://www.oecd.org/tad/agricultural-policies/36661816.pdf

Okitsu, S. (2005). Factors controlling geographical distribution in savanna vegetation in Namibia. African Study Monographs, 30(March), 135-151.

Okogbenin, E., Setter, T. L., Ferguson, M., Mutegi, R., Ceballos, H., Olasanmi, B., \& Fregene, M. (2013). Phenotypic approaches to drought in cassava: review. Frontiers in physiology, 4(May), 93.

Peter, J. V. S. (1994). Feeding strategies, taxonomy and evolution. Nutritional ecology of the ruminant (second edi., Vol. 32, p. 28). New York: Cornell University Press.

Peterson, A. T., \& Shaw, J. (2003). Lutzomyia vectors for cutaneous leishmaniasis in Southern Brazil: ecological niche models, predicted geographic distributions, and climate change effects. International Journal for Parasitology, 33(9), 919-931. http://dx.doi.org/10.1016/S0020-7519(03)00094-8

Peterson, A. T. (2006). Uses and requirements of ecological niche models and related distributional models. Biodiversity informatics, 3, 59-72.

Poulton, C., Kydd, J., \& Dorward, A. (2006). Overcoming Market Constraints on Pro-Poor Agricultural Growth in Sub-Saharan Africa. Development Policy Review, 24(3), 243-277. http://dx.doi.org/10.1111/j.1467-7679.2006.00324.x

Ramirez-Villegas, J., Lau, C., Hooker, J., Jarvis, A., Ann-Kristin, K., Arnell, N., \& Johannes, S., (2011). Climate Analogues: finding tomorrow's agriculture today. CGIAR research program on climate change, agriculture and food security, (working paper no. 12). 
Ramirez-Villegas, J., Jarvis, A., \& Läderach, P. (2013). Empirical approaches for assessing impacts of climate change on agriculture: The EcoCrop model and a case study with grain sorghum. Agricultural and Forest Meteorology, 170, 67-78. http://dx.doi.org/10.1016/j.agrformet.2011.09.005

Randall, D. A., \& Wood, R. A. (2007). Climate Models and Their Evaluation. AR4 WG1 IPCC (pp. 590-662).

Ring, M. J., Lindner, D., Emily, C., \& Schlesinger, M. (2012). Causes of the Global Warming Observed since the 19th Century. Atmospheric and Climate Sciences, 02(04), 401-415. http://dx.doi.org/10.4236/acs.2012.24035

Rondon, M. A., Lehmann, J., Ramírez, J., \& Hurtado, M. (2006). Biological nitrogen fixation by common beans (Phaseolus vulgaris L.) increases with bio-char additions. Biology and Fertility of Soils, 43(6), 699-708. http://dx.doi.org/10.1007/s00374-006-0152-z

Scott, G. J., Rosegrant, M. W., \& Ringler, C. (2000). Roots and Tubers for the 21st Century Trends, Projections, and Policy Options (pp. 1-64).

Silanikove, N. (1997). Why goats raised on harsh environment perform better than other domesticated animals Serie A : Seminaires mediterraneens. Retrieved from http://om.ciheam.org/om/pdf/a34/97606135.pdf

Singarayer, J. S., \& Valdes, P. J. (2010). High-latitude climate sensitivity to ice-sheet forcing over the last 120kyr. Quaternary Science Reviews, 29(1-2), 43-55. http://dx.doi.org/10.1016/j.quascirev.2009.10.011

Somé, L., Sissoko, K., Zougmoré, R., Traoré, B., Amadou, M., Moussa, A. S., Forch, W., et al. (2011). Climate Change, Agriculture and Food Security ( CCAFS ) Summary of Household Baseline Survey Results: Tougou, Burkina Faso December 2011. CCAFS Report, (December 2011).

Tao, F., Yokozawa, M., \& Zhang, Z. (2009). Modelling the impacts of weather and climate variability on crop productivity over a large area: A new process-based model development, optimization, and uncertainties $\begin{array}{llll}\text { analysis. Agricultural and Forest } & \text { Meteorology, 149(5), }\end{array}$ http://dx.doi.org/10.1016/j.agrformet.2008.11.004

Thomas, D. S. G., Twyman, C., Osbahr, H., \& Hewitson, B. (2007). Adaptation to climate change and variability: farmer responses to intra-seasonal precipitation trends in South Africa. Climatic Change, 83(3), 301-322. http://dx.doi.org/10.1007/s10584-006-9205-4

Thuiller, W., Lavorel, S., Brotons, L., \& Arau, M. B. (2004). Effects of restricting environmental range of data to project current and future species distributions. Ecography, 27(September 2003), 165-172. http://dx.doi.org/10.1111/j.0906-7590.2004.03673.x

Veloz, S., Williams, J. W., Lorenz, D., Notaro, M., Vavrus, S., \& Vimont, D. J. (2012). Identifying climatic analogs for Wisconsin under 21st-century climate-change scenarios. Climatic Change, 112, 1037-1058. http://dx.doi.org/10.1007/s10584-011-0261-z

Wimmer, R. (2001). Sample size calculator. Roger Wimmer websites. Retrieved from http://www.rogerwimmer.com/mmr9e/samplesizecalculator.htm

\section{Copyrights}

Copyright for this article is retained by the author(s), with first publication rights granted to the journal.

This is an open-access article distributed under the terms and conditions of the Creative Commons Attribution license (http://creativecommons.org/licenses/by/3.0/). 